\title{
Artículo especial: Obras maestras del arte universal y la medicina: El enfermo imaginario de Molière (1622-1673)
}

Universal art masterpieces and medicine: The imaginary invalid by Molière (1622-1673)

Carlos G. Musso*

Musso CG. El enfermo imaginario de Molière (1622-1673). Evid Act Pract Ambul. Abr-Jun 2013;16(2):60.

\begin{abstract}
Argumento
Argan es un hipocondríaco que demanda permanentemente todo tipo de remedios, purgas y sangrías a su médico, el Dr Purgón. Béline, su esposa, está deseosa de enviudar a fin de poder disfrutar de la fortuna de su marido. Toinette, la criada de la casa, está al tanto de ello y decide ponerla en evidencia. Le pide entonces a Argan que simule estar muerto, éste acepta realizar la farsa y logra observar que mientras Béline no puede disimular su alegría, Angélique, su hija, se muestra dolida, pese a que su padre se opone a la unión entre ella y su amado Cléante. Hasta ese momento Argan pretendía que su hija contrajera matrimonio con el hijo de un médico (Dr. Diafoirus) del que ella no estaba enamorada. Sin embargo, la genuina actitud de tristeza de Angélique es reconocida por Argan, quien decide liberarla de dicho compromiso, con la sola condición de que Cléante se convierta en médico. Finalmente, Argan es convencido por su hermano de que él mismo deviniese médico, tras lo cual, le realizan una parodia de ceremonia de graduación en su propia casa.
\end{abstract}

\section{Ejemplos en el texto}

- La aprensión de Argán por la enfermedad llega al paroxismo: “...quiero tener un yerno y parientes médicos, para procurarme buenos auxilios contra mi enfermedad, tener en mi familia la fuente de los remedios que necesito, y un cómodo acceso a consultas y recetas..."

- El doctor Diafoirus confiesa que le desagradan los pacientes que pretenden ser curados, entonces la criada Tognette burlonamente le dice:

\section{Referencias}

1. Molière El enfermo imaginario. Buenos Aires. Losada. 1974

2. Bordonove G. Molière. Buenos Aires. El Ateneo. 2006

3. Mnouchkine A. Molière. 1978 (film)

4. Tirard L. Molière. 2007 (film)
“... ¡Eso sí que es gracioso! ¡Son muy impertinentes al querer que usted los cure! Usted no está para eso: está para recibir sus honorarios y recetarles remedios..."

\section{Molière y los médicos}

En esta obra Molière critica burlonamente tanto a las personas hipocondríacas, como a los médicos inescrupulosos que se aprovechan de ellas. Si bien es conocida la aversión que Molière sentía por los médicos, debe tenerse en cuenta por un lado, su enconada enemistad con algunos facultativos (uno de los críticos más virulentos de sus obras y el propietario de la casa donde Molière vivía), y por otro, seguramente lo poco que pudo aliviarlo de su afección respiratoria, la precaria y especulativa medicina del siglo XVII. Cuando Molière escribió esta comedia estaba gravemente enfermo y le restaban tan solo unas semanas de vida. De hecho se descompuso mortalmente actuando durante su estreno. Por medio de esta obra, Molière se burló no sólo de la enfermedad y de los médicos, sino también de la mismísima muerte, a la que supo recibir con una carcajada cuyo eco resuena hasta nuestros días.

Concluimos entonces que la comedia El enfermo imaginario de Molière refleja con humor e ironía las miserias de la hipocondría y de la medicina desnaturalizada.

Recibido el 30/06/2013 y aceptado el 01/07/2013

* Servicio de Nefrología del Hospital Italiano de Buenos Aires carlos.musso@ hospitalitaliano.org.ar 